in that neighbourhood until either there was a sufficient tectonic change to lead to an unbalance greater than could be compensated by glaciation or atmospheric effects, or until the distribution of land and water had been so modified as to destroy the mechanism of the trap. There would then have followed another period of hunting until a new trap became operative. The recent observations of fossil magnetism of rocks and sediments show such great promise that we can expect before long to have a good indication of the movements of the pole that have, in fact, occurred in geological history. It is known already that a movement of at least some regions relative to the position of the pole is indicated by the results, and this constitutes a further item of observation along with such geological items as the glaciation of now tropical zones, that force geophysicists to consider that either continental drift or polar movement must have occurred on a substantial scale. In due course the magnetic data will make the distinction between the two. The occurrence of continental drift over great distances would imply new and surprising data about the construction of the earth and in particular its crust; while the occurrence of wandering of the poles over great distances would fit in well with all that is known about the earth, and would reaffirm what can already be inferred from other data.

1 Jeffreys, H., "The Earth" (Camb. Univ. Press, 3rd edit., 1952).

${ }^{2}$ Mintz, Y., and Munk, W., Mon. Not. Roy. Astro. Soc., Geophys. Supp., 6, No. 9 (1954).

s Walker, A. M., and Young, A., Mon. Not. Roy. Astro. Soc. (in the press).

- Bondi, H., and Gold, T., Mon. Not. Roy. Astro. Soc. (in the press).

${ }^{5}$ Holmberg, E. R. R., Mon. Not. Roy. Astro. Soc., Geophys. Supp., 6, No. 6 (1952)

- Darwin, G. H., Phil. Trans. Roy. Soc., Pt. 1, 167 (1877).

"Munk, W., and Revelle, R., Amer. J. Sci., 250 (1952).

Munk, W., and Revelle, R., Mon. Not. Roy. Astro. Soc., Geophys. Supp., 6, No. 6 (1952).

- Melchoir, P. J., Obs. Roy. Belgique, Mon. 3 (1954).

\section{SCIENTIFIC INTELLIGENCE AND DEFENCE}

\section{BY CHAPMAN PINCHER}

CCIENTISTS in Britain are to play a much bigger $\$$ part in Intelligence work as a result of recent changes effected by the Defence Ministry. Ad hoc panels of scientists and technologists expert on particular matters are to be set up to help in the interpretation and collation of certain kinds of information collected through Intelligence sources.

These scientists will be drawn from the universities and from industry as well as from Government establishments. After security clearance they will be asked to assist in the analysis of information about foreign weapons, equipments and defence potentialities.

Since the War, responsibility for this type of work has rested nominally with the rather small Directorate of Scientific Intelligence in the Defence Ministry. That arrangement has proved to be impracticable. The Fighting Services have become so technical that it is no longer possible to draw a line between the routine Intelligence work for which they should be held responsible and scientific Intelligence. In fact, Intelligence chiefs have despaired of defining scientific Intelligence except in the general terms that it is the knowledge and appraisal by scientific methods of foreign developments in science and technology.
The Directorate of Scientific Intelligence has therefore ceased to exist as a separate unit. It has been absorbed into the Joint Intelligence Bureau, which, though still retaining its name, has been given much wider functions.

'The Joint Intelligence Bureau will henceforth serve as a central Intelligence agency to which a wide range of strategic Intelligence information will be transmitted. Its staff will be responsible for ensuring that the utmost possible use is made of such information.

This change brings the British system more closely into line with the Intelligence methods adopted by the United States Government after the War. The failure to appreciate the imminence of the Japanese attack on the American Fleet at Pearl Harbour was later attributed to defects in the higher levels of the Intelligence system. Information clearly pointing to the attack and its approximate date was available in the various separate Intelligence agencies; but because there was no central authority it had never been properly 'appreciated' and had not been put forward at the levels where decisions are made. The U.S. Central Intelligence Agency, now headed by Mr. Allen Dulles, brother of Secretary of State John Foster Dulles, was therefore set up to ensure proper utilization of Intelligence information in the future. Its necessity has been enhanced by the growing danger of the possibly decisive influence in future wars of 'Atomic Pearl Harbours'. All Intelligence information from the Fighting Services, the Secret Service and the Atomic Energy Commission is now canalized to the U.S. Central Intelligence Agency.

The British reorganization has left the Fighting Services responsible for their own operational Intelligence work - an arrangement which is thought to be more flexible as it leaves the Services less isolated from the central agency. It is believed that the people who interpret scientific Intelligence will be more effective if they retain closer connexion with the Service in which they themselves are most expert.

Major-General Sir Kenneth Strong, former chief of the Joint Intelligence Bureau, remains head of the enlarged organization. Mr. H. S. Young, who has been acting director of scientific Intelligence since the resignation of Prof. R. V. Jones from that post last year, has been appointed a deputy director of the Joint Intelligence Bureau.

After collation by the Bureau, matters of import. ance will be put forward to the Joint Intelligence Committee, a high-level group which includes the heads of all the Intelligence agencies and a Foreign Office representative. This committee will produce a 'considered view' on the matters in hand and make it available to Service commanders, ministers, senior Civil servants, ambassadors and others who need it.

The enlarged Joint Intelligence Bureau is responsible to the Defence Minister, Mr. Harold Macmillan, who has a direct voice in the Cabinet. As an additional link with the Joint Intelligence Committee and the Intelligence chiefs, a post of Scientific Adviser on Intelligence to the Defence Minister has been created as part of the new arrangements. Mr. E. C. Williams, formerly director of operational research in the Admiralty, has been appointed to it.

Though these changes have been made entirely on the basis of British experience, it is believed they will cause satisfaction in Washington-an important consideration, as fears about British security have held up interchange of information on atomic weapons and other defence developments. 